\title{
FEATURES OF THE QUALIFICATION OF CRIMES IN THE FIELD OF ECONOMICS BY OBJECT OF CRIME
}

\author{
Izzat Tulkinovich Achilov \\ Independent Researcher of Tashkent State University \\ of Law Senior Prosecutor of Syrdarya regional prosecution office \\ of the Division of the prosecutor's office, \\ Republic of Uzbekistan
}

Article DOI: https://doi.org/10.36713/epra2950

\begin{abstract}
The concept of the object of crime is central to the theory of criminal law, while its content has been at the forefront of scientific debate for more than a century. The problem is that this category is multifaceted and has various aspects: philosophical, axiological, social and legal. In order to determine the content of this concept in the modern doctrine of criminal law, the author sets the task to identify the essence of the object of the crime as a social and legal phenomenon, to delimit its concept from another, similar in meaning to the concept of the object of criminal law protection and to clarify the meaning of the scientific term "object of crime".
\end{abstract}

KEY WORDS: object of crime, act, corpus delicti, signs of corpus delicti.

\section{INTRODUCTION}

In law enforcement, when qualifying socially dangerous acts in the economic sphere, sometimes difficulties arise in delimiting infringements. This is due to the fact that various types of crime are characterized by the presence of a number of common features for them, and on the other hand, by distinctive features that allow you to distinguish them from each other. Such crimes are usually referred to in the doctrine of criminal law as crimes with similar offenses.

For the accurate and clear application of the norms provided for in chapter $\mathrm{X}$ of the Special Part of the Criminal Code, it is necessary to clearly define the features that allow distinguish between crimes with the similar structures available in this chapter. Undoubtedly, the distinction between the signs of the crimes in question and those of other socially dangerous acts is a prerequisite for the proper qualification of the act.

\section{METHODS}

As is the case with other elements of the corpus deficit, the object of encroachment is one of the criteria to distinguish a crime from other offenses.
A correct understanding of the subject of the violation serves as the basis for solving various issues of the practical application of criminal law in criminal matters in the field of economics [1]. In particular, the identification of the subject of a crime takes place when considering the presence or absence of signs of theft of property, as well as to distinguish between the following: a) theft of another's property from other crimes against property; b) attacks in the economic sphere from crimes in other sections; c) economic crimes from administrative offenses in this field.

\section{RESULTS AND DISCUSSIONS}

So, let us consider how the signs of the subject of a crime affect the differentiation of socially dangerous acts of property acts. The object and subject of the crime provided for in article 170 of the Criminal Code are of a certain nature. In the event of property damage to the owner, public relations regarding the use of property are violated. For example, an entity does not transfer mandatory payments for utilities, heat, and electricity to the owner's fund. Thus, he encroaches on public relations regarding the formation of the fund and causes damage to the owner of the property. The 
subject (matter) of this crime is inventory items that were not made available to the owner as a result of the commission of this crime, but if property damage to the owner by fraud or breach of trust were not committed, they should have arrived.

Consequently, the subject of the crime referred to in Article 170 of the Criminal Code is different in that the perpetrator appropriates property that came out of the possession of one owner or another owner, but should have been placed at the disposal of another owner or owner.

The problem of differentiating crimes against property and environmental crimes related to the illegal taking of natural resources (wild animals, fish, trees, etc.) is one of the most difficult problems in forensic investigative practice.

Currently, according to the approach put forward in criminal law literature, natural resources are transformed into objects of encroachment against property only after a person separates them from their natural habitat. Material objects of the environment that are not exposed to human labor do not have monetary value, therefore, are not considered property and cannot be the subject of theft of another's property [2].

In accordance with applicable law, real estate includes land, subsoil, separate water bodies and other individual natural resources. Therefore, natural resources are property and are included in the civil turnover as property in the manner prescribed by law, that is, they can belong to various entities as such.

Therefore, there are no factors against the fact that these natural objects can be considered the subject (matter) of crimes against property.

In the literature, various points of view are set forth regarding the criteria for delimiting infringement of property against environmental crimes. For example, A. Khabarov believes that legislation on natural resources should follow the path of differentiation of natural resources excluded from civil circulation ("common property") and included in it [3]. It is such natural resources that are the subject of property rights and the subject of crimes specified in chapter $\mathrm{X}$ of the Special Part of the Criminal Code.

I. Klepitsky recommends, as an important criterion for distinguishing an environmental offense from a crime against property, to use the separability of the subject from the natural environment, that is, the presence of the owner of this property [4].

According to A. Tuzlukov, "natural resources inherently have an economic attribute, and therefore, can be recognized as a subject of theft" [5]. The author substantiates this opinion by the fact that the value of the property (as an economic sign) is determined not only by the invested funds, but also by its value, that is, the ability to satisfy certain needs.
In our opinion, the value of a thing should be determined by its characteristics and qualities that are useful to meet the specific needs of the individual. Therefore, the fact that human labor has been invested in a specific natural resource may not affect its nature, but the size of its value. When criminal qualification of crimes against property should take into account the rules of civil circulation of property. According to article 82 of the Civil Code, all objects of civil rights are divided into objects that are excluded from circulation, are in limited circulation, and are in free circulation.

Civil law relations with respect to objects excluded from circulation cannot arise (since they are not recognized as objects of property rights). Most of these things cannot be directed in the interests of a limited circle of persons, so that they can benefit. In this regard, we can agree with the opinion of G.A. Krieger that "the types of property that another person cannot possess or acquire cannot be the subject (matter) of a crime related to the theft of another's property" [6].

According to V.P. Revin, the following are excluded from general civil circulation: a) only objects, objects and property that are state property (for example, state diamond and currency reserves, historical and cultural values of national importance, etc.); b) objects excluded from the general circulation due to the danger to others (for example, radioactive, toxic substances and narcotic drugs); c) objects, objects and property belonging to municipal property (for example, funds of the municipal budget, municipal enterprises) [7].

In our opinion, since the regime of property excluded from circulation implies the impossibility of being in someone else's possession, these objects cannot be the subject of crimes against property. Violations of objects in limited circulation and subject to special registration when transferring rights to another person (including state registration) may qualify as crimes against property (for example, registered shares, non-cash money).

Cash value is one of the most important attributes of a property crime. It should be noted that the legal consequences of the offense, and in particular the legal nature of liability, depend on the value of the property that has become the subject of the infringement. In addition, based on the value of the property that has become the subject of a socially dangerous act, the cost of damage caused by the crime is determined, this is crucial for the proper qualification of the act.

In criminal law literature it is customary to determine the size of stolen property in terms of damage caused. According to Yu.I. Lyapunov, the amount of material damage will depend on the economic value of the object of encroachment. This assessment is expressed in the value and monetary value of the item - the price. In the current criminal 
law, a similar economic assessment of the severity of the consequences for differentiating responsibility for the theft of another's property and, accordingly, penalties for their commission are determined [8]. The interdependence of the consequences and the value of stolen property of others is also emphasized in the works of other scientists [9].

P.S. Yani notes that in most cases the qualification of crimes against property is not determined by the "damage" caused by the crime, but by the "size" of the theft of another's property (extortion, destruction of property). Moreover, the size should be understood as the value of the corresponding property [10].

The conclusion that the amount of theft of property should be assessed in terms of its value, on the one hand, does not allow for taking into account other signs (weight, volume, quantity, etc.) when qualifying crimes against property, and on the other hand, does not prevent compensation for damage caused by a crime in order to satisfy a civil claim.

Analysis of the materials of criminal cases shows that the material costs associated with the theft of another's property, when qualifying a crime, are not included in its size. Such costs include, for example, the cost of repairing or restoring damaged items, as well as the cost of repairing doors, windows, and locking devices that were torn down during the commission of the crime.

Thus, property damage caused by the theft of another's property is determined only by the value of the seized property, other expenses and income not received are not taken into account when qualifying a crime.

A.I. Boytsov believes that if the destruction or damage to property was committed after the seizure of the property, while it was not intended to be seized in anyone's interests, but was done to destroy or damage the property, this action does not require additional qualification in accordance with the norms of the Criminal Code (Art. 173 of the Criminal Code), which provides for liability for the intentional destruction or damage to property. Destruction or damage to property committed during the theft, that is, committed during the seizure of another's property or to conceal the traces of a crime is qualified by the totality of crimes for the theft of another's property and intentional destruction or damage to property [11].

Identifying the real value of stolen property is one of the most serious problems in the practice of law enforcement agencies. Sometimes the victim indicates one value of the property in the theft statement, and the expert's conclusion indicates the other value, which cannot exceed one minimum wage established by law at the time the crime was committed. That is why criminal cases are terminated due to the insignificance of the act.
We believe that when assessing the value of stolen property, it is necessary to take into account the cost of similar goods in this region. This complies with civil law standards, which provides for the following rules: in cases where the price is not provided for and cannot be determined on the basis of the terms of the contract, the execution of the contract must be paid at a price that, in comparable circumstances, is usually charged for similar goods, work or services (article 356 of the Civil Code). The literature draws attention to the fact that there are contradictions in the administrative and criminal legislation regarding the prosecution of theft of another's property [12].

According to article 36 of the Criminal Code, "an act or omission is not a crime, although it falls under the signs of an act provided for by this Code as a crime, but does not have public danger because of its insignificance." According to this definition, the insignificance of an act consists in the fact that an action (inaction) with signs of a crime exists without public danger (for example, a box of matches is stolen). Such acts, in fact, do no harm to property relations, in addition, this type of minor acts is rare, and it is not difficult to find out because of the clarity and accuracy of the statement.

V. Maltsev distinguishes another type of insignificance of the act, taking into account the content of the criminal law: "In this case, the act is recognized as socially dangerous, but its level does not exceed the level of civil, administrative or disciplinary offense, therefore, the act cannot be considered criminal" [13].

In this regard, a natural question arises: how to distinguish an administrative offense from a crime, by what criteria should be distinguished insignificant act and petty theft?

For example, this problem is resolved in the Criminal Code of the Federal Republic of Germany as follows: According to $\S 248 \mathrm{a}$, the theft and misappropriation of items of little value is prosecuted only on the basis of a complaint from the victim. In the legislation of the Republic of Uzbekistan, the issue of the ratio of petty theft as an administrative offense and the insignificance of the act has not yet been resolved.

In criminal law, there is another criterion for determining damage - its significant size. It is used as an aggravating feature in a number of rules providing for liability for crimes related to the theft of another's property, and as part of a crime in the form of intentional destruction or damage to property (part 1 of Article 173 of the Criminal Code) is a mandatory feature.

The eighth section of the Special Part of the Criminal Code, called the "Legal Meaning of Terms", states that significant damage is recognized in the amount of one hundred to three hundred minimum wages. 


\section{CONCLUSION}

All in all, a sign of damage on a large scale can be applied only when committing the theft of property belonging to a citizen. It should be noted that the priority of the ownership of individuals in the protection of property relations does not comply with the principle of equality of protection of all forms of ownership, proclaimed in the Constitution of the Republic of Uzbekistan. In addition, when a criminal assault is committed against the property of a legal entity, this often entails a significant deterioration in their financial condition, sometimes threatening the very existence of an enterprise, institution or organization.

Taking into account the above, in our opinion, it is advisable to extend the aggravating feature of certain forms of theft of another's property - causing significant damage not only to citizens, but also to property of legal entities.

\section{REFERENCES}

1. Vladimirov V.A., Lyapunov Yu.I. Responsibility for mercenary attacks on socialist property. - M., 1996 .- P. 15

2. Comments on the Criminal Code / Under the general. Ed. Yu.I. Skuratov, V.M. Lebedev. - M., 1996 .- P. 336.

3. Khabarov A.V. Crimes against property: the effect of civil law regulation: Author. diss. ... cand. legal sciences. - M., 2008. - P. 13-14.

4. Klepitsky I.A. Real estate as a subject of theft and extortion. - M., 2000 .- P. 16.

5. Tuzlukov A.M. Criminal liability for theft under the current legislation of Russia: Diss. ... cand. legal sciences. - Ryazan, 2001 .-P. 186.

6. Krieger G.A. Qualification of theft of property. M., 1994 .- P. 54.

7. Criminal law of Russia. General and Special Parts: Textbook / Ed. V.P. Revina. - M., 2000 .P. 541.

8. Vladimirov V.A., Lyapunov Yu.I. Responsibility for mercenary attacks on socialist property. - M., 1996 .- P. 61.

9. Plohova V.I. Property damage in the structure of crimes against property // Modern crime (State, trends, means of overcoming): Materials of AllRussian. scientific-practical conf. Yekaterinburg, 1999 .- P. 102.

10. Jani P. Theft: some issues of the subject and damage // Legality. - 1996. - No. 10. - P. 12.

11. Boytsov A.I. Crimes against property. - SPb., 2002. - P. 761-762.

12. Masalan, Tolmachev O. Conflicts of the norms of the Criminal Code of the Russian Federation and the Code of Administrative Offenses of the RSFSR in judicial practice // Russian Justice. 2000. - No. 1. - S. 51; Balakshin V. The problem of administrative responsibility for theft // Legality. - 1997. - No. 4. - P. 33.

13. Maltsev $V$. The insignificance of an act in criminal law // Legality. - 1999. - No. 1. - P. 17. 